\title{
The case for differential capitation fees based on age in British general practice
}

\author{
D M Fleming
}

\begin{abstract}
A study was performed to assess whether the existing differential capitation fees for general practitioners accurately assess differential workloads. Data from the third morbidity study in general practice were used to compare capitation fees with relative workload in differing age and sex groups. The population mix which determined the payment by capitation for the 143 principals in the study provided the basis for examining the advantage or disadvantage the general practitioner got from the existing system. Capitation fees for the elderly underestimated the increased workload by $21 \%$ for those aged $65-74$ and by $54 \%$ for those aged 75 or over but overestimated the workload for male adults aged up to 65 . Nevertheless, $60 \%$ of the participating general practitioners were not advantaged or disadvantaged by more than $2.5 \%$ of their capitation fees ( $\$ 450$ a year for the average practitioner with a list of 2000 patients). Similarly $88 \%$ were not advantaged or disadvantaged by more than $5 \%$; none were advantaged or disadvantaged by more than $10 \%$.
\end{abstract}

A three scale capitation fee for the age groups $0-64,65-74$, and 75 or over should be applied in the ratio of 3:5:7 rather than in the present ratio of $3: 4: 5$, but given the present population mix in practices there is no case for differential capitation fees by sex or differential fees for the age group 0-4 years.

\section{Introduction}

Payment for general practitioners in the United Kingdom includes four main elements: $(a)$ practice allowances, which are independent of district and reflect basic costs in establishing and running practices; $(b)$ direct reimbursement of $70 \%$ of the costs of employing ancillary staff and $100 \%$ of the notional rent of premises; $(c)$ item of service payments for immunisation, maternity care, contraception, some cervical cytology provision, care of temporary residents, and night visits; and $(d)$ capitation fees.
There are currently three bands of capitation fees; in 1987 these were $£ 7.55$ for patients aged under $65, £ 9.80$ for those aged 65-74, and £12.05 for those aged 75 and over. In addition to these basic capitation fees a supplementary fee of $£ 1.54$ per patient is paid for every patient (irrespective of age) over the first 1000 registered with each principal. The relative values of the payments for different age groups have remained reasonably constant over recent years, at $3: 4: 5$ for those aged under 65: those aged 65-74: those aged 75 and over. The justification for differential capitation fees is that older people create a heavier workload than younger ones. Using data from the third general practice morbidity survey I wanted to see whether these differential rates of capitation payment accurately reflected the differential workloads imposed by different age and sex groups.

\section{Methods}

Capitation index-In 1987 the average general practitioner with 2000 patients received $£ 17600$ in capitation fees, representing an average total capitation fee per patient of $£ 8.80$ (this includes an element for the supplementary fee paid for patients over the first 1000). If this value is taken as an index of 100 the relative value of the capitation fee is 95 for patients aged less than 65,120 for those aged 65-74, and 146 for those aged 75 and over. This capitation index was used in comparison with an encounter index (see below) to assess the differential between payment and workload.

Morbidity study data - The third morbidity study in general practice covered 48 practices and included 143 principals. ${ }^{1}$ The practices volunteered, and each principal recorded details of every encounter with a patient during the 12 month study period. An encounter was a problem reported by the doctor at consultation in the surgery. Encounters for preventive care were not included, but a home visit was counted as two encounter units. Details were recorded on about 300000 patients. The average number of consultations per patient recorded during the study was $2 \cdot 71$ for men
Birmingham Research Unit, Royal College of General Practitioners, Birmingham B17 9DB D M Fleming, FRCGP, deputy director

TABLE I-Analysis of capitation and encounter units by age and sex

\begin{tabular}{|c|c|c|c|c|c|c|c|c|c|c|}
\hline \multirow[b]{2}{*}{$\underset{\text { (years) }}{\text { Age }}$} & \multirow[b]{2}{*}{$\begin{array}{l}\text { Capitation } \\
\text { index }\end{array}$} & \multicolumn{3}{|c|}{ Men and women } & \multicolumn{3}{|c|}{ Men } & \multicolumn{3}{|c|}{ Women } \\
\hline & & $\begin{array}{c}\text { Encounter } \\
\text { units }\end{array}$ & $\begin{array}{l}\text { Encounter } \\
\text { index }\end{array}$ & $\begin{array}{l}\text { Encounter } \\
\text { index/ } \\
\text { capitation } \\
\text { index }\end{array}$ & $\begin{array}{c}\text { Encounter } \\
\text { units }\end{array}$ & $\begin{array}{c}\text { Encounter } \\
\text { index }\end{array}$ & $\begin{array}{l}\text { Encounter } \\
\text { index/ } \\
\text { capitation } \\
\text { index }\end{array}$ & $\begin{array}{c}\text { Encounter } \\
\text { units }\end{array}$ & $\begin{array}{l}\text { Encounter } \\
\text { index }\end{array}$ & $\begin{array}{l}\text { Encounter } \\
\text { index } \\
\text { capitation } \\
\text { index }\end{array}$ \\
\hline $0-4$ & 95 & $4 \cdot 57$ & 128 & $1 \cdot 35$ & $4 \cdot 82$ & 135 & $1 \cdot 42$ & $4 \cdot 31$ & 121 & $1 \cdot 27$ \\
\hline $5-14$ & 95 & $2 \cdot 15$ & 60 & 0.63 & $2 \cdot 12$ & 59 & 0.62 & $2 \cdot 18$ & 61 & 0.64 \\
\hline $15-24$ & 95 & $2 \cdot 68$ & 75 & 0.79 & 1.75 & 49 & 0.52 & 3.54 & 99 & 1.04 \\
\hline $25-44$ & 95 & 3.00 & 84 & 0.88 & 1.99 & 56 & 0.59 & 3.94 & 110 & $1 \cdot 16$ \\
\hline $45-64$ & 95 & 3.69 & 103 & 1.08 & $3 \cdot 21$ & 90 & 0.95 & $4 \cdot 15$ & 116 & 1.22 \\
\hline $65-74$ & 120 & $5 \cdot 19$ & 145 & $1 \cdot 21$ & $4 \cdot 87$ & 136 & $1 \cdot 13$ & $5 \cdot 45$ & 153 & $1 \cdot 28$ \\
\hline$\geqslant 75$ & 146 & $8 \cdot 02$ & 225 & 1.54 & $7 \cdot 45$ & 209 & 1.43 & $8 \cdot 32$ & 233 & 1.60 \\
\hline $0-14$ & 95 & $2 \cdot 88$ & 81 & 0.85 & $2 \cdot 94$ & 82 & $0 \cdot 86$ & $2 \cdot 82$ & 79 & 0.83 \\
\hline $0-64$ & 95 & 3.08 & 86 & 0.91 & $2 \cdot 49$ & 70 & 0.74 & 3.65 & 102 & 1.07 \\
\hline$\geqslant 65$ & 130 & $6 \cdot 36$ & 178 & $1 \cdot 37$ & $5 \cdot 76$ & 161 & $1 \cdot 24$ & $6 \cdot 75$ & 189 & 1.45 \\
\hline All & 100 & $3 \cdot 57$ & 100 & 1.00 & $2 \cdot 90$ & 81 & 0.81 & $4 \cdot 19$ & 117 & $1 \cdot 17$ \\
\hline
\end{tabular}


and 4.02 for women. In about $12 \%$ of consultations the doctor made a home visit. The average number of encounter units per patient per year was used as a reference value of 100 to create an encounter index for men and for women and for the following age groups: $\leqslant 4,5-14,15-24,25-44,45-64,65-74$, and $\geqslant 75$.

Comparison of capitation and encounter indexes-The ratio of the encounter index to the capitation index was calculated for each age and sex group. The closer the relation to unity the more closely the capitation fees reflected the relative workload of the different age and sex groups. The ratio of encounter index to capitation index was also calculated for each practice population in the morbidity study using the age and sex groups described above. Results were analysed by the Kruskal-Wallis test.

\section{Results and comment}

Table I shows the average number of encounter units for each age and sex group together with the ratio of capitation to encounter index.

The analysis suggests that men (with a ratio of $0 \cdot 81$ ) represented less work and were therefore more profitable to general practitioners than women, who had a ratio of $1 \cdot 17$. This was true at all ages except in children aged 4 and under. The increased capitation fee for patients aged 65-74 underestimated the increased workload by $21 \%$ and that for patients aged 75 or over by $54 \%$. The capitation arrangements also underestimated the workload among preschool children by $35 \%$. In relative terms, these underestimates were balanced by overestimates in the age group 5-14 in both sexes and for men in all age groups up to 64 . When children aged under 15 were considered together the ratio of encounter to capitation at 0.85 implied no substantial disparity.

TABLE II-Distribution of principals by ratio of encounter index to capitation index

\begin{tabular}{|c|c|c|c|c|c|c|c|c|}
\hline \multirow[b]{2}{*}{ Ratio: } & \multicolumn{3}{|c|}{ Advantaged } & \multicolumn{2}{|c|}{ Intermediate } & \multicolumn{3}{|c|}{ Disadvantaged } \\
\hline & $\begin{array}{l}0.90- \\
0.925\end{array}$ & -0.95 & -0.975 & $-1 \cdot 0$ & -1.025 & -1.05 & $-1 \cdot 075$ & $-1 \cdot 10$ \\
\hline No of prin & $\begin{array}{r}14 \\
4\end{array}$ & 0 & $\begin{array}{r}20 \\
5\end{array}$ & $\begin{array}{l}33 \\
13\end{array}$ & $\begin{array}{l}53 \\
16\end{array}$ & 20 & 1 & 2 \\
\hline
\end{tabular}

Table II shows the ratio of encounter index to capitation index in the morbidity study using the appropriate age and sex bands described above. For 34 principals (nine practices) the ratio was less than 0.975 and for 23 principals ( 10 practices) it exceeded $1 \cdot 025$ These values were used to group general practitioner principals into three groups-advantaged, intermediate, and disadvantaged. In financial terms a difference in ratio of 0.025 was worth about $£ 450$ a year to the general practitioner with a list of 2000 patients.

Some characteristics of the three groups are shown in table III. Although four out of 23 disadvantaged and only one out of 34 advantaged general practitioners were in singlehanded practices, these numbers were too small to be significant. Except for one practice of three partners, advantaged general practitioners were

TABLE III-Characteristics of practice populations by relative financial advantage

\begin{tabular}{|c|c|c|c|}
\hline & Advantaged & Intermediate & Disadvantaged \\
\hline No of principals & 34 & 86 & 23 \\
\hline No of practices & 9 & 29 & 10 \\
\hline Singlehanded & 1 & 6 & 4 \\
\hline \multicolumn{4}{|c|}{ Composition of practice population } \\
\hline Median $\%$ aged $>65$ years & $9 \cdot 6$ & $16 \cdot 0$ & $19 \cdot 9$ \\
\hline Median \% aged $0-4$ years & $8 \cdot 4$ & $5 \cdot 6$ & $5 \cdot 1$ \\
\hline Median $\%$ of men & $49 \cdot 2$ & $47 \cdot 8$ & $45 \cdot 9$ \\
\hline $\begin{array}{l}\text { Median list size per } \\
\text { principal }\end{array}$ & 1776 & 2214 & 2420 \\
\hline
\end{tabular}

separated from disadvantaged by the proportion of elderly people on their lists $(\geqslant 65)$ : for the advantaged principals this ranged from $4 \cdot 4 \%$ to $12 \cdot 4 \%$ and for the disadvantaged principals it ranged from $18 \cdot 1 \%$ to $30.6 \%$. The exception occurred in the disadvantaged group and was an unusual practice with only $5 \cdot 8 \%$ of its population accounted for by the elderly but large proportions accounted for by women $(65.0 \%)$ and children aged $0-4(20 \cdot 1 \%)$. These were the wives and children of military staff registering separately from their husbands and fathers. Though potentially disadvantageous, the proportion of children aged 0-4 was relatively increased in the advantaged group. This apparent paradox arose because of the population mix in each practice, which resulted in a relatively large proportion of children where there was a relatively small proportion of elderly patients.

There was a significant difference in composition by sex with a bias towards men for the advantaged group (Kruskal-Wallis test $\mathrm{H}=26, \mathrm{p}<0.001$ ), but this occurred because of the preponderance of women among the elderly.

There were also highly significant differences between the groups in the average list per principal (Kruskal-Wallis test $\mathrm{H}=15, \mathrm{p}<0.001$ ), with a reduced list for advantaged practices. Average list per principal was weakly associated with the proportion of the elderly ( $r s=0.22, p<0.01)$ and with the proportion of women $(\mathrm{rs}=0.38, \mathrm{p}<0.001)$

\section{Discussion}

If all practices had the same composition (by age group and sex) no useful purpose would be served by differential capitation fees. It is only to the extent that practices differ that capitation fees are necessary, to ensure equitable payment for work done. This is especially important if age is relevant because longevity is increasing. This review was concerned exclusively with age and sex, though other factors, such as place of residence and social class, may also be relevant. The computerisation of family practitioner committee registers opens new opportunities for an elaborate structure of differential capitation fees since calculating practice specific capitation fees can be automated. The justification for such a system would require evidence that the present and comparatively simple system is unfair.

This inquiry used data gathered in a national morbidity study of 143 principals from England and Wales. Because this study was a voluntary one the recruitment of practices may have been biased, but neither of the characteristics studied here, the population mix in practices and the relativity of the workload in different age-sex groups, is likely to have been affected by a systematic bias.

In comparing capitation with workload there were substantial anomalies in some age and sex groups but when comparing them as they affected individual general practitioners few of the anomalies remained. Eighty six $(60 \%)$ of the 143 general practitioners received capitation fees within $2 \cdot 5 \%$ of the value based on encounters. A further 40 principals $(28 \%)$ were within $5 \%$. No general practitioner was advantaged (or disadvantaged) by $10 \%$, a factor worth $£ 1800$ a year to the general practitioner with a list of 2000 patients.

The sex of the patient was a major determinant of workload, and this is not specifically recognised in capitation fees. The composition of the study practices did not show substantial variation by sex and that which did occur was largely secondary to differences in age structure. Hence there is no benefit to be obtained by differential capitation based on sex. This might change, however, if a significant number of practices have a distribution by sex outside the $45 \%-55 \%$ limits. 
There were three practices outside these limits, and one of them, with $61 \%$ men (including a boys' boarding school in a total population of 1845), was in the advantaged group. The other two were in the disadvantaged group and contained $64 \%$ and $65 \%$ of women; one was the practice serving military families and the other was a singlehanded practice of 1650 patients with $30.7 \%$ of elderly people.

The most important finding in this study was the underestimate of relative capitation in those aged 65-74 and 75 and over. The inadequacy of the relative capitation of elderly people was shown in the analysis of encounters and in the analysis of population mix in the practices. The ratio of encounters to capitation was recalculated using the existing age bounds for capitation and applying these in the ratio of 3:5:7. For 129 principals $(90 \%)$ working in 43 of the practices the ratio was within $2 \cdot 5 \%$ of unity. Two practices (four doctors) with large excesses of women remained disadvantaged by $4.6 \%$ and $8.7 \%$ and three practices remained advantaged; one of these was the practice with $61 \%$ of men (advantaged by $7 \cdot 0 \%$ ); the other two (advantaged by $4 \cdot 2 \%$ and $3.7 \%$ ) had especially small proportions of elderly patients. Rank ordering using this scale produced results at the extremes which were very similar to those based on current capitation.

Children aged 0-4 provided a workload for general practitioners which was greater than the average over all ages. Given the population mix that existed within practices, however, it did not matter that this was not specifically recognised in the capitation system. Indeed the advantaged general practitioners had a relatively greater proportion of children. These data suggest that there is nothing to be gained by having an increased capitation fee for young children. The arguments for such a fee could be equally applied to reducing the capitation fee for children aged 5-14.

The relative difference in average list size per principal between advantaged and disadvantaged general practitioners was highly significant, though a surprise. Practices retained the same relative position when the data were analysed on the basis of a capitation index calculated after excluding the supplementary capitation fee. There were weak associations between list size and the proportion of elderly people and list size and the proportion of women, but these findings may have been specific to the study practices and not applicable elsewhere. No conclusion can be reached about this issue without obtaining further data from an independent source.

The third national morbidity study is sponsored by the Department of Health and Social Security and conducted by the Office of Population Censuses and Surveys and the Royal College of General Practitioners. I thank Dr D L Crombie, director of the Birmingham research unit, and Dr K W Cross of the department of social medicine, University of Birmingham, for their help in the preparation of this paper; Mrs C A Norbury for the supplementary analyses of the morbidity study, the Department of Health and Social Security for permission to use the study data (though the conclusions in this paper are mine), and the participating general practitioners, whose disciplined recording was irreplaceable.

1 Royal College of General Practitioners, Office of Population Censuses and Surveys, Department of Health and Social Security. Morbidity statistics from general practice-third national study 1981-1982. London: HMSO, 1986 (Series MB5 No 1).

\section{BOOKS RECEIVED}

\begin{abstract}
Acquired immune deficiency
syndrome

AIDS: a guide to Clinical Counselling. R Miller, R Bor. (Pp 136; 99.95 paperback.) London: Science Press, 1988. back.) London: Science Press, 1988.
Distributed by Cambridge Medical Distributed by Cambridge
Books. ISBN 1-870026-40-3.

The AIDS Bureaucracy. S Panem. (P 208; £17.95 hardback, £7.95 paperback.) Cambridge, Massachusetts: Harvard University Press, 1988. ISBN hardback 0-674-01270-4, paperback 0 674-01271-2.
\end{abstract}

\section{Addiction}

Illicit Drug Use in Portsmouth and Havant. A Local Study of a Nationol Problem. C Brown, J Lawton. (Pp 176 £7.95 paperback.) London: Polic Studies Institute, 1988. ISBN 0-85374-341-X.

\section{Oncology}

Advances in Cancer Research. Vol 49. Ed G Klein, S Weinhouse. (Pp 432; figs; \$75.) Orlando: Academic Press, 1987. ISBN 0-12-006649-1.

Cancer Clinical Trials: Methods and Practice. Ed M E Buyse, M J Staquet, R J Sylvester. (Pp 496; figs; $\{25$ paperback.) Oxford: Oxford University Press, 1988. ISBN 0-19-261765-6. Contributions to Oncology. Vol 29 "Regional Cancer Treatment." Ed K R Aigner, Y Z Patt, K H Link, Kreidler. Series editors $S$ Eckhardt, J H Holzner, G A Nagel. (Pp 320; figs £34.10.) Basel: Karger, 1988. Distributed by John Wiley and Sons. ISBN 3-8055-4762-5.

\section{Ophthalmology}

Atlas of Clinical Ophthalmoscopy. Scuderi, G Morone, R Brancato. Translated from Italian by F C Blodi. (Pp 320; figs and colour plates; $£ 101$.)
Milan: Masson/Chicago: Year Book Medical Publishers, 1987. Distributed by Wolfe Medical Publications. ISBN 0-8151-7737-2.

\section{Orthopaedics}

Self Assessment in Radiology and Imaging 4: Orthopaedics. D J Stoker, E A Tilley. (Pp 224; figs; $£ 19.50$ paperback.) London: Wolfe, 1988. ISBN 0-7234-0909-9.

\section{Paediatrics}

The Child with Febrile Seizures. S J Wallace. (Pp 192; figs; £25.) London: Wright, 1988. Distributed by ButterWright, 1988. Distributed by
worth. ISBN 0-7236-0773-7.

\section{Pathology}

Diagnostic Manual of Tumours of the Central Nervous System. A J Franks. (Pp 160; colour plates; £45.) Edinburgh: Churchill Livingstone, 1988. ISBN 0-443-03524-5.

Methods and Achievements in Experimental Pathology. Vol 13. "Kinetics mental Pathology. Vol 13. "Kinetics and Patterns of Necrosis." Volume and series editor G Jasmin. (Pp 272; figs; $£ 108.20$.) Basel: Karger, 1988.
Distributed by John Wiley and Sons. Distributed by John
ISBN 3-8055-4668-8.

ISBN 3-8055-4668-8. Pathology. Ed E Rubin, J L Farber. (Pp 1600; figs; £35.) Philadelphia: Lippincott, 1988. Distributed by 50698-8.

\section{Pharmacology}

Clinical Pocket Manual. "Drug Interactions." Ed J E Mason, D Schweisguth. (Pp 192; £8.50 spiral bound paperback.) Pennsylvania: Springpaperback.) Pennsylvania: Springby Harcourt Brace Jovanovich. ISBN by Harcourt Brace

Drugs for Rheumatic Disease. Ed H E Paulus, D E Furst, S H Dromgoole.
(Pp 504; figs; £55.) New York: Churchill Livingstone, 1988. ISBN 0 443-08011-9.

Psychiatry

Developmental Psychiatry. Ed $M$ Rutter. (Pp 400; £15 paperback.) Washington DC: American Psychiatric Press, 1988. Distributed by Cambridge University Press. ISBN 0-52135906-6.

Psychiatric Disability. Clinical, Legal and Administrative Dimensions. Ed A Meyerson, T Fine. (Pp 480; £30.) Washington DC: American Psychiatric Press, 1988. Distributed by Cambridge University Press. ISBN 0-88048-210-9.

\section{Radiology}

Advances in Radiation Biology. Vol 13. Ed J T Lett. (Pp 424; figs; \$110.) San Diego: Academic Press, 1987. ISBN 0-12-035413-6.

Imaging Modalities in Spinal Disorders. $M$ E Kricun. (Pp 712; figs; $£ 60$. Philadelphia: Saunders, 1988. Distributed by Harcourt Brace Jovanovich. ISBN 0-7216-1587-2.

\section{Respiratory medicin}

Basic Arterial Blood Gas Interpretation. G L Zagelbaum, M A Welch, Jr, P R Doyle. (Pp 336; figs; $£ 13.50$ paperback.) Boston: Little Brown, 1988. back.) Boston: Little Brown, 1988. Distributed by Churchill

Rheumatology

Clinical Rheumatology Illustrated. F D Hart. (Pp 420; figs; £68.) Sydney: Williams and Wilkins, 1988. ISBN 0-86433-003-0.

Surgery

A Colour Atlas of Surgical Anatomy of the Abdomen in the Living Subject. $\mathbf{R}$ Calne. (Pp 168; figs and colour plates; £35.) London: Wolfe/Chicago: Year Book Medical Publishers, 1988. ISBN Wolfe 0-7234-0888-2, Year Book 0-8151-1464-8.

\section{Third World}

Health Care in India-An Appraisal. G P Dutta. (Pp 128; Rs 30.) 1988. Published by Dr $\mathrm{P} \mathrm{K}$ Choudhuri, 15/1C North Road, Jadavpur, Calcutta 700032 , India.

\section{Ultrasonics}

Fetal Echocardiography. An Atlas. K L Reed, C F Anderson, L Shenker. (P 148; figs; \$62.50.) New York: Liss, 1988. Distributed by John Wiley and Sons. ISBN 0-8451-4250-X.

\section{Urology}

Ureteroscopy. J L Huffman, D H Bagley, E S Lyon. (Pp 208; figs; \{28.50.) Philadelphia: Saunders, 1988. Distributed by Harcourt Brace 1988. Distributed by Harcourt B
Jovanovich. ISBN 0-7216-2148-1.

\section{Miscellaneous}

Medicine: Diagnosis and Treatment. Ed R W Schrier. (Pp 576; figs; £16.95 paperback, Boston: Litte Brown, 1988. Distributed by Chure Brown ingstone. ISBN 0-316-77484-7.

The Metronomic Society. Natural Rhythms and Human Timetables. M Young. (Pp 320; £16.95.) London: Thames and Hudson, 1988. ISBN 0-500-01443-4.

New Library of Pastoral Care. "Going Somewhere. People With Mental Somewhere. People With Mental Handicaps and Their Pastoral Care." S
Hollins, M Grimer. General Editor D Hollins, M Grimer. General Editor D
Blows. (Pp 140; 44.95 paperback.) Blows. (Pp 140; $£ 4.95$ paperback.)
London: The Society for Promoting Christian Knowledge, 1988. ISBN 0-281-04336-1.

No Memorial. The Story of a Triumph of Courage Over Misfortune and Mind Over Body. A Babington. (Pp 248; £9.95.) London: Cooper, 1988. ISBN 0-85052-074-6.

Poisonous Plants and Fungi. An Illustrated Guide. M R Cooper, A W Johnson. (Pp 134; colour plates; $\$ 8.95$ paperback.) London: Her Majesty's Stationery Office, 1988. ISBN 0-11242718-9.

Policy Studies Institute. "Making the Most of Daylight Hours." M Hillman. (Pp 122; figs; $\{4.95$ paperback.) London: Policy Studies Institute, 1988. ISBN 0-85374-421-1.

The Politics of Food. G Cannon. (Pp 382; 66.95 paperback.) London: Century, 1988. ISBN 0-7126-1717-5. Rapid Access Guide to the Physical Examination. D W Novey. (Pp 552; figs; $£ 17$ paperback.) Chicago: Year figs; 17 paperback.) Chicago: Year Book Medical Publishers, 1988. Distions. ISBN 0-8151-6434-3.

Road Accident Statistics. T P Hutchinson. (Pp 320; £28.) 1987. Available from Rumsby Scientific Publishing, PO Box 76, Rundle Mall, Adelaide, South Australia 5000. ISBN 0-73160653-1.

The Smoke-Free Guide. How to Eliminate Tobacco Smoke from Your Environment. A Galloway. (Pp 160; figs; 